\title{
Fast pyrolysis biochar in eucalyptus seedling production
}

\begin{abstract}
The main species of Brazilian forestry is Eucalyptus, this specie is adapted to our soil and climatic conditions, also we have hybrids and clones ideally suited for different timber uses and the silvicultural treatments are well know. The experiment was set up with nursery substrate (NS) and mixtures of NS with biochar (BC) at 20, 40, 60, 80 and $100 \%$ to evaluate the seedling production of Eucaliptussp. clones VM01 and I144. Stem diameter, height, number of sheets, fresh and dry weight of roots and shoots and Dickson index were evaluated.The $\mathrm{BC}$ did not improve seedling growth compared to NS, but ratios below to $10 \%$ should be considered for this purpose.
\end{abstract}

Keywords: agroindustrial waste, clones, quality index of Dickson
Volume 7 Issue 5 - 2020

\author{
Samara Mazette, ${ }^{1,2}$ Marina Moura Morales, ' \\ Jair Carmo, ${ }^{2}$ Flávia Miranda, ${ }^{3}$ Francisco José \\ Moura, ${ }^{3}$ Ednaldo Andrade ${ }^{2}$ \\ 'Embrapa Florestas, Estrada da Ribeira, Brazil \\ ${ }^{2}$ Universidade Federal de Mato Grosso-UFMT, Brazil \\ ${ }^{3}$ Departamento de Engenharia Química e de Materiais, Pontifícia \\ Universidade Católica do Rio de Janeiro, Brazil
}

Correspondence: Marina Moura Morales, Embrapa Florestas, Estrada da Ribeira, Km I I I, Guaraituba, Caixa Postal 319, CEP 834I I-000 Colombo, PR, Brazil,

Email marina.morales@embrapa.br

Received: August 24, 2020 | Published: September 29, 2020

\section{Introduction}

In the 1940s, large eucalypt plantations were established in Southeastern of Brazil. The main purpose was for charcoal, a renewable material for coke fuel. Eucalyptus was chosen as a forestry option in Brazil based on the species variety, potential for adaptation to soil and climatic conditions, availability of genetically-improved seed and material for vegetative propagation, the existence of hybrids and clones ideally suited for different timber uses and the availability of knowledge about silvicultural treatments and techniques. The main species of Eucalyptus in Brazilian forestry are: E.saligna E. citriodora, E. camaldulensis, E.urophylla, E. grandis and the hybrids E.urophylla $x$ E. grandis known as "urograndis"; E.grandi,s $x$ E. camaldulensis known as "grancam" and E.urophylla $x$ E.camaldulensis known as "urocam". ${ }^{1}$

The success of a planted forest begins with the seedlings. The survival potential in the field largely depends on seedling quality, which is higher when the seedlings are formed on favorable substrates to the initial plant development. A suitable substrate to high-quality seedlings formation should have a high water-holding capacity and nutrient availability by Cunha, uniform composition by Dantasand adequate aeration to provide rooting of seedlings by kratz. Based on these characteristics, biochar has a great potential as a component of seedling substrates. ${ }^{2-6}$

However, appropriate substrate for rooting depends on the type of biochar (technology production, temperature, time retention and others) and species of seedlings, propagation system and availability of components. It is worth remembering that some questions remain about the utility of biochar as a soil/substrate amendment, such as the toxicity and salinity of its leachate, $\mathrm{pH}$ effect on nutrient bioavailability and addition rates. ${ }^{7}$ Therefore, the main aim of this study was to use biochar obtained by fast pyrolisis for eucalyptus seedling production, considering seedling quality aspects.

\section{Material and methods}

\section{Biochar pyrolysis and characterization}

The fast pyrolysis biochar was made from Eucalyptus sawdust.
This biochar was the by-product of bio-oil extraction produced in a fluidized bed reactor ( $200 \mathrm{~kg} \mathrm{~h}^{-1} 112$ capacity) made by Suzano. The process was conducted between 480 to $500^{\circ} \mathrm{C}$, with pressure between 70 to $100 \mathrm{~mm} \mathrm{H} 2 \mathrm{O}$, residence time of 8 seconds, and in an atmosphere of $10 \%$ air. The determination of total nutrients content present in the fast pyrolysis biochar was obtained by acid extraction, the analyzes were performed with ICP OES-Perkin Elmer equipment. ${ }^{8}$

\section{Study site, seedling preparation and greenhouse incubation}

The local climate is AM (Köppen's classification), tropical monsoonal, with a dry winter and a hot rainy Summer. Mean annual temperature is $24^{\circ} \mathrm{C}$ with an average rainfall of $1900 \mathrm{~mm} / \mathrm{yr}$. Eucalyptus clones mini cuttings commercially known as VM01 (E. urophyllax E. camaldulensis) e I144 (E. urophyllax E. grandis) from the Flora

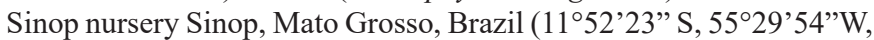
elevation $=384 \mathrm{~m} \mathrm{ASL}$ ) was used for seedling development. We used a randomized complete design, with ten treaments, three replicates, and 48 seedlings per plot.

The treatments consisted of the following substrates: Nursery substrate (NS), composed by carbonized rice husk, coconut fiber, sawdust and rice rusk ashes $(1: 1 \mathrm{~m} / \mathrm{m})$; and mixtures NS with biochar (BC) at 20, 40, 60, 80 and 100\%, labeled as $0,20,40,60,80$ and $100 \%$, respectively. The treatments were fertilized with Basacote $6 \mathrm{M}(3 \mathrm{~kg}$ $\left.\mathrm{m}^{-3}\right)$ and magnesium thermo phosphate $\left(2 \mathrm{~kg} \mathrm{~m}^{-3}\right)$. The propagules were collected in a clonal minigarden, immersed in rooting hormone indolbutiric acid, placed in plastic tubes with substrates mentioned above and replaced in greenhouse at temperature range between $30-35^{\circ} \mathrm{C}$ and $85 \%$ of humidity for 20 days, after the seedlings were replaced to full sun for 90 days. ${ }^{9-12}$

Stem diameter, height and number of sheets were measured every 30 days after planting, until 120 days. Seedlings were harvested when reached the commercial size for transplanting (120 days) and fresh and dry weight of roots and shoots were also obtained. Dry weight was obtained after drying the material at $60^{\circ} \mathrm{C}$ for 72 hours. The quality index of Dickson (QID) was calculated according to the equation

$$
Q I D=T D M /(H / D+S D M / R D M)
$$


in which: TFM is the total dry biomass (g); SDW, shoot dry weight $(\mathrm{g})$; RDM, root dry weight $(\mathrm{g})$; $\mathrm{H}$, height $(\mathrm{cm})$; and $\mathrm{D}$, stem diameter (mm).

\section{Statistical methods}

The statistical analysis was performed considering One-way analysis of variance. Means were compared with Dunnet test, at 5\% of probability. All statistical analyses were accomplished with the program Statistica version 9.0.

\section{Results and discussion}

\section{Biochar and nursery substrate characterization}

The substrates chemical composition, showed major difference in $\mathrm{P}, \mathrm{Zn}, \mathrm{Ca}$ content and $\mathrm{pH}$, Table 1. The $\mathrm{pH}$ governs many plant-soil chemical relations, particularly the availability of micronutrients and toxic ions, due to its influence on solubility. The ideal $\mathrm{pH}$ range in nursery management is 5.5 to 6.5 . The $\mathrm{pH}$ value from NS was lower compared with the values observed in $\mathrm{BC}$. This characteristic is important once, nutrients as $\mathrm{P}, \mathrm{Fe}, \mathrm{Zn}$ and $\mathrm{Cu}$ can become unavailable for plant uptake on $\mathrm{BC}$.

\section{Seedling growth and yield}

The presence of $\mathrm{BC}$ in the substrates showed lower seedling quality than NS for both clones, Figure 1. The NS treatment is significant higher than $\mathrm{BC}$ treatments for height (19\%), stem diameter $(18 \%)$ and number of leaves $(16 \%)$ for the clone I144 and height $(18 \%)$, stem diameter $(16 \%)$ and number of leaves $(24 \%)$ form the clone VM01, (Figure 1). Higher values of stem diameter, height and number of leaves are quite desirable in the production of seedlings, since these variables are key parameters to estimate the performance, initial growth and survival at the field after planting.

Table I Chemical properties of the fast pyrolysis biochar used in this study made from Eucaliptus sawdust

\begin{tabular}{|c|c|c|c|c|c|c|c|c|c|}
\hline \multicolumn{10}{|c|}{ Fast pyrolysis biochar } \\
\hline $\mathrm{pH}$ & $P$ & K & $\mathrm{Ca}$ & $\mathrm{Mg}$ & B & $\mathrm{Cu}$ & $\mathrm{Fe}$ & $M n$ & $\mathrm{Zn}$ \\
\hline & \multicolumn{4}{|c|}{----g kg-I(dry weigh) --- } & \multicolumn{5}{|c|}{-----mg kg -I (dry weight) ------- } \\
\hline 7.8 & 0.67 & 5.4 & 9.2 & 1.4 & 14 & 29 & 2506 & $|7|$ & 385 \\
\hline \multicolumn{10}{|c|}{ Nursery substrate Chemical Properties } \\
\hline $\mathrm{pH}$ & $P$ & K & $\mathrm{Ca}$ & $\mathrm{Mg}$ & B & $\mathrm{Cu}$ & $\mathrm{Fe}$ & $M n$ & $\mathrm{Zn}$ \\
\hline & \multicolumn{4}{|c|}{--g kg-I (dry weight) -- } & \multicolumn{5}{|c|}{--------mg kg -I (dry weight) ------ } \\
\hline 6.2 & 2.9 & 4.5 & 4.5 & 2.1 & 13 & 15 & 1921 & 233 & 47 \\
\hline
\end{tabular}

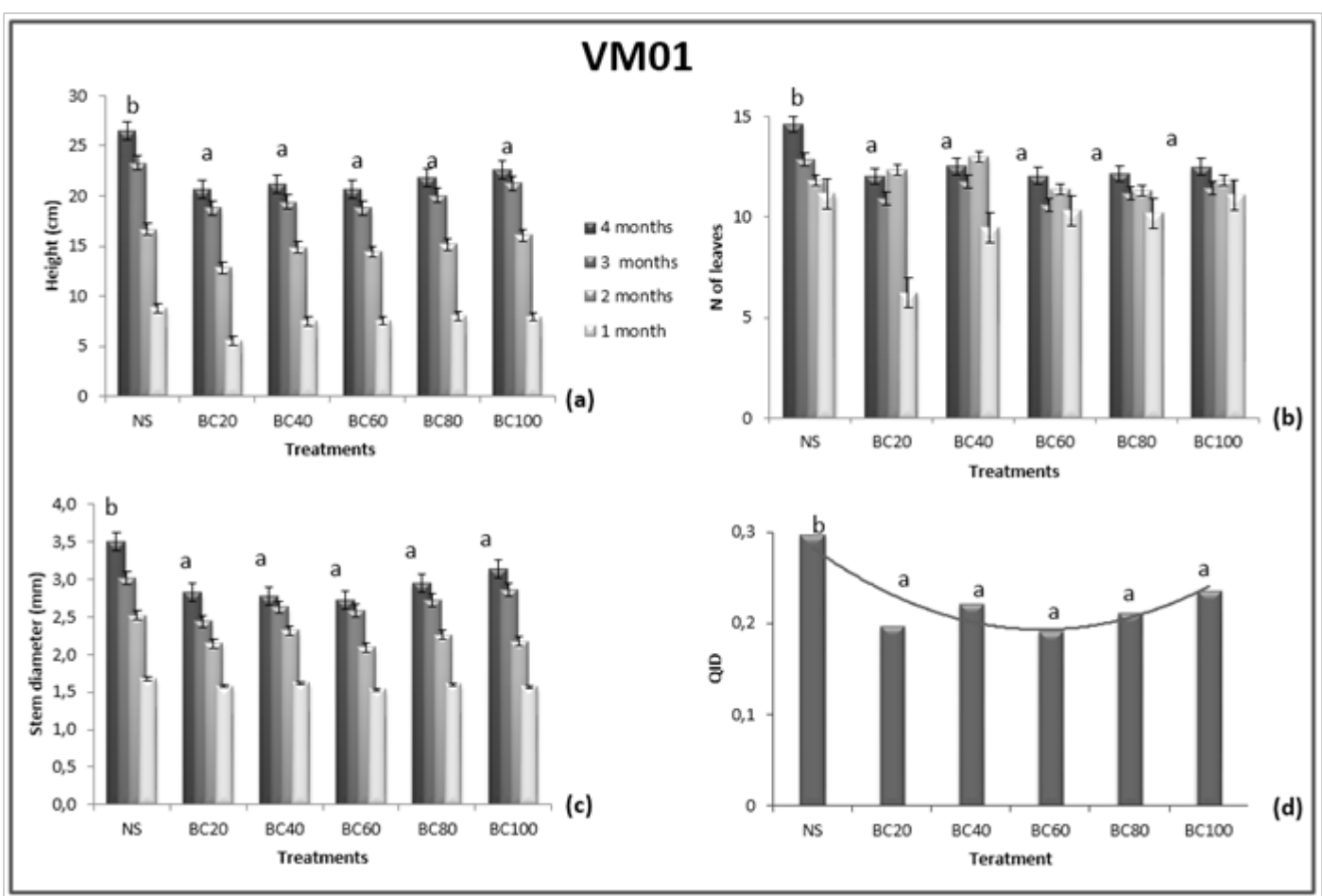

Figure I Height (a), number of leaves (b), stem diameter (c) and quality index of Dickson (QID) (d) for clones of eucalyptus seedlings II 44 and VM0 I in different substrates: NS, $100 \%$ substrate used in nurseries and fast pyrolysis biochar (BC). The numbers following the BC initials indicate the biochar rates (\%) used in the mixture with NS. Means followed by equal letters do not differ by Dunnet, at $5 \%$ probability at 4 months. Error bars represent the standard errors. 
This general decrease in the seedling growth could be mainly due to the higher $\mathrm{pH}$ observed in $\mathrm{BC}$ (7.8), since it reduces the availability of some nutrients such as, $\mathrm{Zn}, \mathrm{Cu}, \mathrm{Fe}$ and $\mathrm{Mn}$. This high $\mathrm{pH}$ is due to the $\mathrm{BC}$ free ash content (16.8\%) accumulated on burning process. The $\mathrm{pH}$ is an essential aspect for the potential use of a material as substrate, since it constitutes a restrictive aspect for plant growth. Also, high doses of biochar may have induced nitrogen deficiency, due to the high $\mathrm{C} / \mathrm{N}$ ratio of the biochar.

The root fresh and dry weight, respectively, were also influenced by the factors substrate type, plant species and substrate mixture. All the variables considered (substrate type, dose and crop species) also affected the ratio aerial/root biomass ratio. This parameter provides information about the strength of the root system and its ability to withstand transplantation in the field: high values of this parameter indicate a risk of failure of crop development under field conditions.

All these variables are needed to provide a Dickson quality index (DQI), that is a good indicator of seedling quality because it considers the robustness and the distribution equilibrium of biomass in the plants. 1The NS yielded the highest DQI values, 0.93 and0.77 in the I144 and VM01 plants, respectively. Rezende tested biochar and activated biochar in Teach seedlings and founded that biochar does not improve quality parameters ofseedlings, in comparison with the commercial substrate, but activated biochar with $25 \%$ was enough to improve seedling growth performance to the same level as commercial substrate. Petter in 202 founded that $7.5 \%$ of biochar addition to the substrate promoted a better quality eucalyptus seedlings, while ratio above $15 \%$ provide reduction. Based on that, fast pyrolysis biochar addition to substrate with ratio below to $10 \%$ should be considered as seedling substrate.

The root fresh and dry weight, respectively, were also influenced by the factors substrate type, plant species and compost dose. The highest values of both were obtained for NS (4.92 g and $2.21 \mathrm{~g}$, respectively for $\mathrm{I} 144$ and 2.86 and $1.43 \mathrm{~g}$ for VM01), while $\mathrm{BC}$ substrate gave values lower than those observed with NS. These data are compatible with those presented by Zanetti et al. (2003), in which they did not verify the phytomass gain in lemon saplings with $20 \%$ of biochar addition to the substrate, also with $30 \%$ of biochar addition in eucalyptus seedlings. However, differing from data was observed by Souchie. which verified that the addition up to $50 \%$ of biochar in substrate, provided linear increases in dry mass of root and shoot for the species Tachi-gali vulgaris (carvoeiro do cerrado).

\section{Conclusions}

The biochar ratiostested is not a viable strategy for the proper management of eucalyptus seedlings, but ratios below to $10 \%$ should be considered for this purpose. Is important to remember that biochar can present good results for seedling growth, but ratios should be adjusted. The Clone I144 presented better response to seedling development compared to VM01.

\section{Acknowledgments}

To Jaldes Langer from Flora Sinop nursery for technical and financial support.

\section{Conflicts of interest}

The authors declare that there was no conflict of interest.

\section{References}

1. AMS. Minas Gerais Silviculture Association. Forestry: social, economic and environmental development with forest plantations. Belo Horizonte: Minas Gerais Silviculture Association. 2004. 18 p.

2. Amaral FHC, JCA Nobrega, RSA Nobrega, et al. Growth of Leucaena Leucocephala (Lam.) De Wit Favored by Organic Waste in the Brazilian Semiarid Region. Revista Brasileira De Engenharia Agricola E Ambiental. 2016;20(7):612-617.

3. Costa E, AR Sassaqui, AK da Silva, et al. Seedlings: Biomasses and Biometric Relations in Different Farming Environments and Substrates. Part Ii', Engenharia Agricola. 2016;36(2):229-241.

4. Jara-Samaniego J, MD Perez-Murcia, MA Bustamante, et al. Composting as Sustainable Strategy for Municipal Solid Waste Management in the Chimborazo Region, Ecuador: Suitability of the Obtained Composts for Seedling Production. Journal of Cleaner Production. 2017;141:13491358 .

5. Landis TD, RG Nisley, USF Service. The Container Tree Nursery Manual: Containers and Growing Media, U.S. Department of Agriculture, Forest Service; 1990.

6. Mbagwu JSC, Piccolo A. Effects of humic substances from oxidized coal on soil chemical properties and maize yield. In: Drozd J, Gonet SS, Senesi N, editors. The role of humic substances in the ecosystems and in environmental protection. IHSS, Polish Society of Humic Substances, Wroclaw, Poland; 1997. p. 921-925.

7. Morales MM, N Comerford, IA Guerrini, et al. Sorption and Desorption of Phosphate on Biochar and Biochar-Soil Mixtures. Soil Use and Management. 2013;29(3):306-314.

8. Petter FA, FR Andrade, B Marimon, et al. Biochar Conditioner as Substrate for the Production of Eucalipto Seedlings. Revista Caatinga. 2012;25(4):44-51

9. Rezende FA, V dos Santos, C Maia, et al. Biochar in Substrate Composition for Production of Teak Seedlings. Pesquisa Agropecuaria Brasileira. 2016;1(9):1449-1456.

10. Sanchez-Monederu MA, A Roig, J Cegarra, et al. Composts as Media Constituents for Vegetable Transplant Production. Compost Science \& Utilization. 2004;12(2):161-168.

11. Souchie FF, BH Marimon, FA Petter, et al. Charcoal as Amendment to Substrate of Seedlings of Tachigali Vulgaris Lg Silva \& Hc Lima. Ciencia Florestal. 2011;21(4):811-821.

12. Zanetti M. The use of byproducts of vegetal charcoal on growth of 'Rangpur' lime rootstock under screen house. 2003;25(3):508-512. 